RÓKA Eszter', KHAYER Bernadett', DÉRI Dániel², KIS Zoltán², SCHULER Eszter', MAGYAR Nóra², PÁLYI Bernadett², PÁNDICS Tamás', VARGHA Márta'

'Nemzeti Népegészségügyi Központ, Közegészségügyi Laboratóriumi Főosztály, Budapest; ${ }^{2}$ Nemzeti Népegészségügyi Központ, Mikrobiológiai Referencia Laboratóriumi Főosztály, Nemzeti Biztonsági Laboratórium, Budapest

E-mail: roka.eszter@nnk.gov.hu

DOI: https://doi.org/10.29179/EgTud.2021.3.11

\title{
A hazai szennyvíz-alapú COVID-19 elörejelző rendszer
}

\section{Összefoglalás:}

A szennyvíz alapú epidemiológia a szennyvízre közösségi mintaként tekint. A módszer nem új, azonban a CoVID-19 járványban került a figyelem középpontjába. A SARS-CoV-2 a széklettel már a tünetek megjelenése előtt ürül, így szennyvízben előbb indul emelkedésnek a vírus örökítőanyagának koncentrációja, minthogy a betegek megjelennének az egészségügyi ellátórendszerben.

Az NNK 2020 júliusa óta heti rendszerességgel vizsgálja a megyeszékhelyek szennyvizét, a vizsgálat kb. 3,9 millió főt reprezentál. A minták koncentrálása egyedi ultraszúrő membránon történik, a mennyiségi meghatározást RT-qPCR módszerrel végezzük (N1 gén). Variáns kimutatásra digital droplet PCR-t alkalmazunk.

A szennyvíz eredmények a második, és a harmadik hullám során is jól jelezték előre mind a diagnosztizált COVID-19 esetszám alakulását, mind a kórházi ápolásra szorulók számát. Az országos átlagot tekintve legszorosabb összefüggést a 2 héttel késöbbi új esetszámmal találtunk. A negyedik hullámban a koncentrációk először július második felében mutattak kiugrást, a növekedés azonban nem egyenletes.

Az alfa variáns elterjedése a szennyvíz segítségével is nyomon követhető volt. Vizsgálataink igazolták, hogy az új típus vagyon gyorsan, mindössze néhány hét alatt vált dominánssá 2021. január közepe és március közepe között. A delta variáns jelenléte szintén kimutatható a nyár közepe óta.

Az eredmények közlése hetente (szokatlan változás esetében azonnal) történik az Országos Tisztiföorvos, valamint az Operatív Törzs felé. Lakossági kommunikációra a koncentrációkat és tendenciákat kategóriákba soroljuk, amelyeket szintén hetente jelenítünk meg az NNK honlapján.

2021 októberétől a SARS-CoV-2 kimutatása és variánsainak azonosítása a 150000 főnél nagyobb települések szennyvíz mintáiból Európai Uniós előírássá válik az Európai Bizottság 2021/472 ajánlása értelmében. A vizsgálatok nem csak a SARS-CoV-2, hanem egyéb, akár a jövőben megjelenő vírusok nyomon követése révén hozzájárulnak a járványügyi biztonságunkhoz.

Kulcsszavak: SARS-CoV-2, szennyvíz alapú epidemiológia, variáns kimutatás 